\title{
Article
}

\section{The Impact of Entrepreneurial Passion on the Entrepreneurial Intention; Moderating Impact of Perception of University Support}

\author{
Temoor Anjum $1,2, * \mathbb{D}$, Petra Heidler ${ }^{3, * \mathbb{D}}$, Azadeh Amoozegar ${ }^{2}$ and Rao Tahir Anees ${ }^{2}$ \\ 1 Department of Business Administration, Faculty of Management Sciences, Ilma University, \\ Karachi 72400, Pakistan \\ 2 Centre of Post-Graduate Studies, Limkokwing University of Creative Technology, Cyberjaya 63000, Malaysia; \\ azadeh.amoozegar@limkokwing.edu.my (A.A.); aneesrao82@gmail.com (R.T.A.) \\ 3 Department of International Business and Export Management, IMC University of Applied Sciences Krems, \\ 3500 Krems an der Donau, Austria \\ * Correspondence: tamooranjum@yahoo.com (T.A.); petra.heidler@fh-krems.ac.at (P.H.)
}

Citation: Anjum, Temoor, Petra Heidler, Azadeh Amoozegar, and Rao Tahir Anees. 2021. The Impact of Entrepreneurial Passion on the Entrepreneurial Intention; Moderating Impact of Perception of University Support. Administrative Sciences 11: 45. https://doi.org/ 10.3390/admsci11020045

Received: 13 March 2021

Accepted: 19 April 2021

Published: 26 April 2021

Publisher's Note: MDPI stays neutra with regard to jurisdictional claims in published maps and institutional affiliations.

Copyright: (c) 2021 by the authors. Licensee MDPI, Basel, Switzerland. This article is an open access article distributed under the terms and conditions of the Creative Commons Attribution (CC BY) license (https:/ / creativecommons.org/licenses/by/ $4.0 /)$.

\begin{abstract}
Passion is fundamental to starting a business because it stimulates motivation, improves intellectual activity, and provides meaning for daily work. This research investigates the role of entrepreneurial passion as a prelude to entrepreneurial intention. The theory of planned behavior was used as an underpinning theory. A conceptual framework was developed and tested to determine their contributions to entrepreneurial intentions. The correlation between entrepreneurial passion and entrepreneurial intentions is moderated by perception of university support to determine if it enhances the entrepreneurial intention to become a successful entrepreneur. The sample $(\mathrm{N}=395)$ was identified using a convenience sampling technique and is comprised of university business students in the province of Punjab, Pakistan. The questionnaire comprised two sections used for data collection, and Smart-PLS was used to analyze the hypotheses. The findings have indicated that there is a strong positive relationship between entrepreneurial passion and entrepreneurial intentions. The analysis showed that the concept of university support alleviates the relationship between entrepreneurial passion and entrepreneurial intention. The moderation effect of perception of university support on the association between entrepreneurial passion and entrepreneurial intention was recognized in this study. Thus, it called for exploring this moderating effect from other perspectives. As an implication to policy, the government bodies should ensure students have access to an entrepreneurial atmosphere. Specifically, the ministry of education and HEC Pakistan could consider this for the design of university syllabuses, thereby leading to more impactful education of entrepreneurship.
\end{abstract}

Keywords: entrepreneurial passion; entrepreneurial intention; perception of university support; theory of planned behavior

\section{Introduction}

Entrepreneurship is the foundation and engine of any economic development of the country. Entrepreneurship is a competitive behavior that drives not only the new market and employment creation but also the work of innovation in the market that can pay to economic growth. The role of an entrepreneur is like a locomotive of economic broadening and job establishment, and it is also the driver of innovation in a country (Mandongwe and Jaravaza 2020). Promoting individual entrepreneurship has always been a focus of business research, which has led to a multitude of studies trying to recognize the factors that predict entrepreneurial intention. Entrepreneurial intention is well known for being a reliable predictor of actual entrepreneurial behavior (Anjum et al. 2018c, 2019; Fayolle and Liñán 2014). Entrepreneurial intention developed a person's interest in doing a business rather than a job. Since intention is considered the best predictive factor for behavior, 
an in-depth understanding of parameters affecting EI is essential for evaluating business behavior (Ajzen 1991; Krueger et al. 2000).

Among the factors identified is Entrepreneurial Passion (EP), which is considered an important feature of supporting and driving an entrepreneurial career, along with EI (Biraglia and Kadile 2016). EP is a strong positive feeling experienced by consciously gaining strong positive emotion and participating in business activities related to a role that is meaningful to the self-identification of the entrepreneur (Cardon et al. 2009). Earlier research has confirmed that entrepreneurial passion can build self-confidence and influence EI inpeople who are not yet formally or actively involved in entrepreneurship (De Mol et al. 2019; Karimi 2019). EP motivates entrepreneurs to identify opportunities and construct new businesses, and it shows that passion is seen as an important part of business motivation, and success leads to EI (Collewaert et al. 2016; Murnieks et al. 2014). Given its crucial role in the business process, it would be important to understand how EP relates to EI and the subsequent experience. Most passion studies focus on individual EP in relation to the results associated with organizations and other results that are behavioral (Murnieks et al. 2016). Therefore, entrepreneurial passion is an important factor in entrepreneurial intentions, and research needs a deeper understanding of the fundamental importance of EP for entrepreneurial actions.

Considering the socio-economic benefits of entrepreneurship between fresh students, most academic institutions, governments, and other public strategy supporters are interested in learning about factors that shape EI and create an ecosystem conducive to new entrepreneurship. Thus, it is important to understand the psychological and contextual factors affecting EI, one of which is EP (Anjum et al. 2018b; Türk et al. 2020). Personal and social factors, including the impact of the university environment on EI, but the part of university support in promoting intent should be established appropriately. The reshaping of students' intention in the learning process is very eastern (Liñán et al. 2011). Therefore, a delicate understanding of this relationship is essential. This study presents the view that university support is a possible host of these relationships.

It should be a prime objective of higher education institutions teaching graduates to look for work and create employment opportunities. Entrepreneurial intention is a construction that is commonly used in the examination of the effect of entrepreneurial education (Joensuu-Salo et al. 2020). Entrepreneurs in Pakistan say that the academic community lacks entrepreneurial spirit, including its university environment activities (Farrukh et al. 2016). The discussion and application of entrepreneurial universities fit a hot topic in the academy. However, many universities' focal point is the academic world, and few universities are involved in the world of professionals and entrepreneurs (Saeed et al. 2013).

In the context of the previous argument, the two main objectives of this research are: first, it employs diverse contexts to validate EP (founding, inventing, developing) and EI, thus expanding the universality of these relationships in business literature; second, this study provides a detailed understanding of the EP and EI relationship by suggesting and validates the moderating role of Perception of University Support (PUS). These findings further clarify possible situations in different aspects of the EP-EI relationship and understand how an enabling environment to shore up PUS characteristics can lead to high EI, even with limited resources.

\section{Literature Review}

Passion is an observable phenomenon in the business process, and the lack of passion leads to the disconnection of entrepreneurs, which leads to the collapse of entrepreneurship (Cardon and Kirk 2015). Therefore, given the critical role of passion in business success, it is logical to develop passion before generating risk. By participating in business activities related to your own significant identity, you can consciously obtain a strong positive feeling. A strong positive attitude is directed at events that are important to the individual and, therefore, more persistent (Cardon et al. 2009; De Mol et al. 2019). Since other studies 
have identified the importance of persistence as a critical driver of business success and entrepreneurial passion is an essential contributor to this persistence, it is perhaps unique (De Mol et al. 2019). Therefore, we must study the passion and explore it further.

\subsection{Entrepreneurial Passion to Entrepreneurial Intention}

Entrepreneurial passion is an important factor for entrepreneurial intentions. Therefore, researchers demand a greater understanding of the fundamental importance of passion for their entrepreneurial activities (Cardon et al. 2009). A study conducted on passion, and more, focus on personal entrepreneurial passions related to organizational results and behavioral outcomes, emphasizing entrepreneurial intentions (Cardon et al. 2013). Studies that link passion with intention are indirect, often dealing with passion as a regulator between individual factors and intentions and as a precursor to constructs that affect intention (Murnieks et al. 2014). A current business environment requires the constant feedback of new startups, usually the development of high startups. There appears to be a lack of entrepreneurial drive in developed countries with a generally high education level (Joensuu et al. 2013).

The requirement to measure EP is that we believe the strong positive emotions of passion and the relevance of identity centers to tasks and activities that are particularly relevant to entrepreneurship (Collewaert et al. 2016). Although the overall task of being an entrepreneur may be an object of passion, a more rational approach focuses on three different parts. Entrepreneurs may experience these differences, but they are always at the core of the business process in a variety of ways. The first is to invent new products or services, the second is to establish new organizations, and the third is to develop these organizations after their initial survival and accomplishment (Cardon et al. 2009; Cardon et al. 2013). Each function involves a different set of tasks and activities that reflect challenges related to the business process's additional features (Cardon et al. 2013).

These three passionate roles of invention, creation and development are essentially multidimensional in the areas of activity associated with entrepreneurship. In practice, EP's experience with these activities can vary, both from the background and challenges faced by entrepreneurs at every stage of the company's development, as well as by the specific experience and life experience of different entrepreneurs (Cardon et al. 2005; Cardon et al. 2013). This means that the understanding of the EP does not need to be unified in all three areas, and the entrepreneur's passion for a particular activity may vary. This means that EP levels three areas may vary depending on the sex, age, point of education, or current age of the entrepreneur to start a business and the number of startups in the past (Cardon et al. 2013).

Activities related to the invention and scanning of environments to find novel market opportunities, develop new products or services, and use the new model. Entrepreneurship is often associated with significant changes in economic or social patterns (Cardon et al. 2009; Cardon et al. 2013). Some entrepreneurs are looking for innovative ideas more deeply and more often than others. The desire to bring new solutions to the market is often an important motivation for entrepreneurs (Katbla and Ahuja 2002). People passionate about inventions can actively seek new opportunities, enjoy the presentation of new concepts of products or services, and enjoy the invention of new solutions. These people like to patch new product designs and explore their expression in specific applications (Cardon et al. 2009; Cardon et al. 2013).

The passion for inventing is related to the integration of the financial, human, and social resources needed to create a new business. For many entrepreneurs, the desire to build an organization is an important motivating factor. The founder's role is complex and central to the self-concept of the entrepreneur (Cardon et al. 2009; Cardon et al. 2013). Entrepreneurs often need achievement, as reflected in establishment activities, which demonstrate that they have achieved some business achievements. Entrepreneurs passionate about entrepreneurship mainly enjoy the entrepreneurship process and often expand identities that are intertwined with business characteristics (Cardon et al. 2005). 
For example, an entrepreneur with a high entrepreneurial passion is a regular entrepreneur. This refers to people who have launched several new businesses in their careers (Westhead and Wright 2015). Some of these entrepreneurs are interested in starting a business and quickly entrust business management to others or sell the company to start their next company or invention (Wardatulaina et al. 2017).

The passion for development is related to the growth and expansion of startups. Many entrepreneurs are not motivated by a desire to find an organization but by consciously developing and expanding their businesses (Cardon et al. 2009; Cardon et al. 2013). These people tend to present organizational management strategies that are different from those of their peers. They also begin to depend on different management styles to interact with key stakeholders in a manner that facilitates the continued expansion of the organization (Bazzy et al. 2019). In many cases, entrepreneurs with a high degree of enthusiasm for development do so in their own startups, and it is equally reasonable for non-entrepreneurs to experience entry into existing startups and development in more sustainable, valuable, or sustainable startups (Cardon et al. 2013).

Furthermore, extensive studies on EI have empirically shown that EP is a significant analyst of EI (Neneh 2020; Karimi 2019; Biraglia and Kadile 2016; Anjum et al. 2020b). Some studies have also conceptually and empirically investigated the role of entrepreneurial passion or its proxies in the entrepreneurship process, and especially about variables like venture growth, behavior, and or entrepreneurial action. The past studies had been much in line with the conceptualization of entrepreneurial passion as harmonious, resulting in positive affect and engaging willingly in a chosen enjoyable activity (Vallerand et al. 2003; Mageau and Vallerand 2007; Vallerand et al. 2008). Based on the arguments stated above, the following research hypotheses were developed:

Hypotheses 1 (H1). EPI is positively associated with EI.

Hypotheses 2 (H2). EPF is positively associated with EI.

Hypotheses 3 (H3). EPD is positively associated with EI.

\subsection{The Moderating Role of Perception of University Support}

Universities are considered a source of fostering innovation and entrepreneurial spirit. Universities can play a significant role in positively manipulating students' intentions and efforts toward entrepreneurship and making them able to develop a new venture (Anjum et al. 2021). Universities can provide support in specific ways by instilling the skills and knowledge necessary for business creation. Universities can also provide targeted support to the students. The targeted support may include help in concept development and starting a new business (Anjum et al. 2020b).

Therefore, universities should play a key role in promoting entrepreneurship and encouraging students to use it as a viable professional option. Although few researchers have analyzed the role of entrepreneurship education in the training of student EI (Souitaris et al. 2007), the role of universities has not been studied as a provider and enabler of an environment conducive to nurturing EI leading to new venture creation (Ali and Abou 2020). For developing economies, mainly developing Asian economies, there is a scarcity of research on the relationship between EI with PUS (Nabi et al. 2017). Anjum et al. (2018a) and Turker and Selcuk (2009) believe that entrepreneurship education, especially the university education system, plays a vital part in the growth of students' entrepreneurial intentions.

Since universities support students in a variety of ways, it is important to understand the effectiveness of these initiatives and the degree to which they can influence students to make entrepreneurship a career choice (Mustafa et al. 2016). According to Neneh (2020), support can be obtained in the form of physical resources, emotional support, and financial assistance (scholarships). In this study, only university support will be considered as 
specific educational courses, loans to a startup business, workshops, motivational support, and internship programs.

Additionally, it has been suggested that entrepreneurial intensity, which is a proxy for $\mathrm{EP}$, is related to intuitive intentions. Passion is, therefore, seen to produce the feeling and the experience of getting closer to entrepreneurial activities among students (BonnevilleRoussy et al. 2013). The attitude, behavior, and entrepreneurial indulgence of students can foster the intention and desire to initiate new business endeavors in the future (Ahmed et al. 2019; Anjum et al. 2020c). Thus, entrepreneurial intention among students is a dynamic and vibrant area that needs further exploration to grasp and appreciate the technique for instituting new businesses. The tendency to start a business is influenced by certain aspects, such as internships and incubators of companies supported by the university (Fayolle and Gailly 2015).

While people with a high degree of passion for entrepreneurship have confidence in their business knowledge and skills and are more likely to have a high willingness to start a business, the positive impact is unlikely to be consistent with everyone (Neneh 2020). Developing entrepreneurship intention among students seems to be a collective task. Entrepreneurial orientation, entrepreneurial self-efficacy, business incubation program, facilitation, and social support system may have a complex and mutual influence on students' feelings and emotions, which intensifies entrepreneurial intentions (Saeed et al. 2015; Adekiya and Ibrahim 2016).

There is a need for university support and motivation to enhance EI of the students. Given the lack of literature, this study mainly analyses universities' key regulatory role in growing students' EI. The support obtained from the university is essential to change a person's belief in their ability to perform a number of tasks and to increase a person's motivation and desire to start a business (Lee et al. 2011; Sahban et al. 2016). Furthermore, previous studies have observed that the university environment indirectly influenced entrepreneurial intentions. In contrast, the university environment's role in promoting aim by strengthening the effects of factors known to influence intention needs to be established (Aman et al. 2012). Therefore, this study assumes that entrepreneurial passion (inventing, founding, and developing) directly impacts EI, which the PUS will moderate. Accordingly, the following assumptions can be set:

Hypotheses 4 (H4). PUS moderates the relationship between EPI and EI Entrepreneurial Intention.

Hypotheses 5 (H5). PUS moderates the relationship between EPF and EI Entrepreneurial Intention.

Hypotheses 6 (H6). PUS moderates the relationship between EPD and EI Entrepreneurial Intention.

\section{Research Framework}

Figure 1 introduces a conceptual model that explains how entrepreneurial passion affects the EI moderate impact of PUS. The Theory of Planned Behavior (TPB) has been an influential model in offering a sound and mostly applicable theoretical framework to improve the understanding and prediction of entrepreneurial intention and considerpersonal and social factors (Nyock et al. 2014; Ajzen 2011; Ferreira et al. 2016; Iglesias-Sánchez et al. 2019). The purpose of TPB is to explain how a person's interests reflect the conduct or behavior of a person doing something (Ajzen 1991). TPB was used because of its comprehensive, compatible theoretical specification and the large amount of cross-disciplinary research dedicated to testing, expanding, and criticizing the intention model (Joensuu et al. 2015). After this argument, passion is expected to have a positive relationship with EI. This association is supported by extensive research (Anjum et al. 2020b; Karimi 2019; Neneh 2020). 


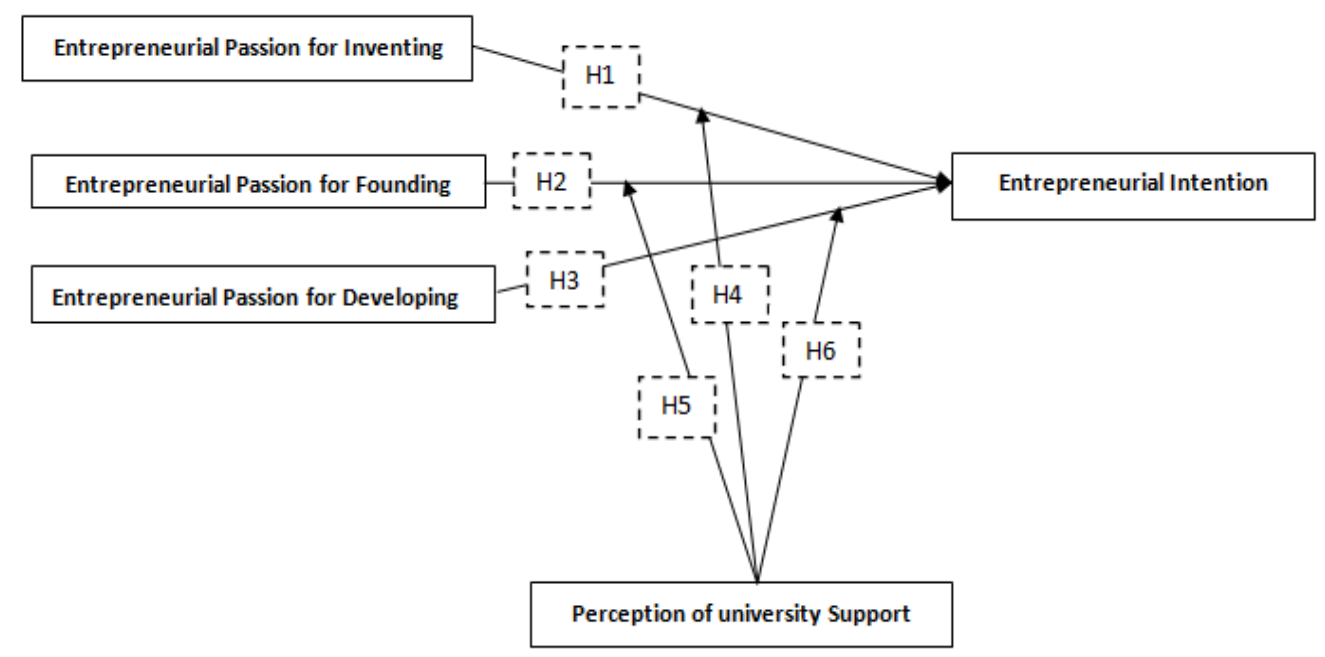

Figure 1. Conceptual Framework.

Farrukh et al. (2017) already validated EI in the Pakistani context with a Cronbach's alpha value of 0.798. The Entrepreneurial Passion Scale was adopted from Cardon et al. (2013), which was in the Pakistani context with a CR value of 0.789 (Anjum et al. 2020a; Anjum et al. 2018b). Both scales consist of six and five items, respectively. Perception ofuniversity support was adopted from Keat et al. (2011) and tested by Anjum et al. (2020b, 2021). The questionnaire of this study is added in Appendix A for further use.

\section{Methodology}

The data described in this paper were collected as part of a large study designed to test the relationship between Entrepreneurial Passions that shape Entrepreneurial Intention. A survey was conducted among only business students specializing in entrepreneurship in Pakistan. The sample $(\mathrm{N}=395)$ was identified using a convenience sampling technique and is comprised of university students in the province of Punjab, Pakistan. First, students taking these courses are more likely to start a company. Second, students face crucial career choices in their final year and are considered to have a good idea of their future what they wanted to do (Farrukh et al. 2019a). For this research, a cross-sectional and quantitative research design was used based on the survey method. Structural equation modeling (SEM) of partial least squares (PLS) was used to analyze the results, and Smart-PLS was used to run the PLS-SEM (Farrukh et al. 2019b; Nazar et al. 2020; Zreen et al. 2019). PLS-SEM is used in $95 \%$ of studies related to entrepreneurship (Manley et al. 2020).

\section{Data Analysis}

PLS-SEM is a two-step procedure that involves evaluation measurement and structural models (Anderson and Gerbing 1988; Ansari et al. 2021), which can demonstrate a study's robustness by exemplifying measuring, mediating, and moderating variables in a hierarchical model. In this study, PLS outperforms covariance-based SEM (CB-SEM) in estimating a formative hierarchical model by avoiding the various constraints of CB-SEM model complexity, which supports existing entrepreneurship studies (Manley et al. 2020). The evaluation of the measurement model includes the assessment of factor loading $(0.70$ threshold value). Composite reliability ( 0.70 threshold value), average variance extracted (0.50 threshold value), and discriminant validity (Hair et al. 2017). Table 1 shows that all the latent variables' factor loadings were well above the threshold value of 0.70 . Next, we assessed the composite reliability (CR) and average variance extracted (AVE). CR is the internal consistency of the items in the scale. In contrast, AVE is the measure of the amount of variance that is captured by a construct in relation to the amount of variance due to measurement error (Hair et al. 2017). Table 1 also shows that CR and AVE's threshold values are achieved hence fulfill the requirement of the CR and AVE (Hair et al. 2017). 
Table 1. Measurement model (FL, Cronbach's $\alpha, \mathrm{CR}$, and AVE).

\begin{tabular}{|c|c|c|c|c|}
\hline Latent Variables & Factor Loading & Cronbach's $\alpha$ & CR & AVE \\
\hline $\begin{array}{l}\text { Entrepreneurial Passion for } \\
\text { Inventing }\end{array}$ & & 0.959 & 0.961 & 0.745 \\
\hline EPI1 & 0.785 & & & \\
\hline EPI2 & 0.758 & & & \\
\hline EPI3 & 0.715 & & & \\
\hline EPI4 & 0.811 & & & \\
\hline EPI5 & 0.825 & & & \\
\hline $\begin{array}{l}\text { Entrepreneurial Passion for } \\
\text { Founding }\end{array}$ & & 0.857 & 0.902 & 0.720 \\
\hline EPF1 & 0.756 & & & \\
\hline EPF2 & 0.714 & & & \\
\hline EPF3 & 0.825 & & & \\
\hline EPF4 & 0.854 & & & \\
\hline $\begin{array}{c}\text { Entrepreneurial Passion for } \\
\text { Developing }\end{array}$ & & 0.883 & 0.894 & 0.669 \\
\hline EPD1 & 0.715 & & & \\
\hline EPD2 & 0.749 & & & \\
\hline EPD3 & 0.778 & & & \\
\hline EPD4 & 0.732 & & & \\
\hline EPD5 & 0.793 & & & \\
\hline EPD6 & 0.801 & & & \\
\hline Entrepreneurial Intention & & 0.917 & 0.929 & 0.708 \\
\hline EI1 & 0.785 & & & \\
\hline EI2 & 0.809 & & & \\
\hline EI3 & 0.779 & & & \\
\hline EI4 & 0.821 & & & \\
\hline EI5 & 0.819 & & & \\
\hline $\begin{array}{l}\text { Perception of University } \\
\text { Support }\end{array}$ & & 0.953 & 0951 & 0.685 \\
\hline PUS1 & 0.751 & & & \\
\hline PUS2 & 0.723 & & & \\
\hline PUS3 & 0.741 & & & \\
\hline PUS4 & 0.749 & & & \\
\hline PUS5 & 0.814 & & & \\
\hline
\end{tabular}

For this, the DV the AVE value's square root should be greater than the square correlation with other structures (Fornell and Larcker 1981). Table 2 results indicate that the DV has been completed and that the latent structure's correlation is compared with the square root of the average variance extracted (Fornell and Larcker 1981). Table 1 also shows each square root of the average variance obtained exceeds the underlying structure's correlation. Therefore, this indicates that enough DV has been achieved. 
Table 2. Discriminant validity (Fornell and Larcker criteria).

\begin{tabular}{cccccc}
\hline Constructs & EI & EPF & EPI & EPD & PUS \\
\hline EI & 0.841 & & & & \\
\hline EPF & 0.654 & 0.848 & & & \\
\hline EPI & 0.658 & 0.458 & 0.863 & & \\
\hline EPD & 0.451 & 0.652 & 0.611 & 0.817 & 0.827 \\
\hline PUS & 0.592 & 0.596 & 0.496 & 0.658 & \\
\hline
\end{tabular}

According to (Hair et al. 2017), there are various strategies to analyzing the DV: the Fornell-Larcker criterion and the cross loading heterotrait-monotrait ratio (HTMT). Because of the weaknesses of the Fornell-Larcker criterion and the HTMT criterion is also used in this study; thus, we used the HTMT ratio, as suggested by Henseler et al. 2009. The results presented in Table 3 show that HTMT values are below the fundamental assumption of 0.85 , indicating that there is no DV challenge.

Table 3. Discriminant validity (HTMT Ratio).

\begin{tabular}{cccccc}
\hline Constructs & EI & EPF & EPI & EPD & PUS \\
\hline EI & & & & \\
\hline EPF & 0.369 & & & \\
\hline EPI & 0.409 & 0.357 & & \\
\hline EPD & 0.401 & 0.496 & 0.489 & 0.521 \\
\hline PUS & 0.399 & 0.559 & 0.359 & \\
\hline
\end{tabular}

\subsection{Structural Model Assessment}

A structural model assessment is used to evaluate the relationship between latent constructs and validate the conceptual model (Hair et al. 2014; Wong 2013). After evaluating the measurement model, the present research examined the structural model by performing bootstrap on 5000 replicates to evaluate the significance of path coefficient significance (Hair et al. 2017; Henseler et al. 2009). (H1), (H2), and (H3) were supported entirely, meaning EP (inventing, founding, and developing) positively impacted EI and can improve students' EI as we can see these effects are shown in Table 4.

Table 4. Direct Effect.

\begin{tabular}{ccccc}
\hline Hypothesis & Path & Path Coefficient & $\boldsymbol{t}$-Statistics & $\boldsymbol{p}$-Values \\
\hline$(\mathrm{H} 1)$ & $\mathrm{EPI} \rightarrow \mathrm{EI}$ & 0.104 & 3.125 & 0.000 \\
\hline$(\mathrm{H} 2)$ & $\mathrm{EPF} \rightarrow \mathrm{EI}$ & 0.217 & 2.987 & 0.002 \\
\hline$(\mathrm{H} 3)$ & $\mathrm{EPD} \rightarrow \mathrm{EI}$ & 0.098 & 3.259 & 0.001 \\
\hline
\end{tabular}

\subsection{Moderation Analysis}

In this study, it is assumed that (H4), (H5), and (H6) can demonstrate the moderating effect of perception of university support on the relationship between entrepreneurial passion for inventing, entrepreneurial passion for founding, entrepreneurial passion for developing, and entrepreneurial intention. Andrew F. Hayes used the 5000 boot effect to perform an interactive effect check on SPSS using Model 1 in process macro v3.0 (Hayes 2007). The results report that perception of university support positively moderates the relationship between entrepreneurial passion (inventing, founding, and developing). The results of the moderation study that revealed the constructive linkages are seen in Table 5. The effect of restraint must then be contrasted with the direct impact, which identifies that perception of university support has been a larger impact. 
Table 5. Moderation Effect.

\begin{tabular}{|c|c|c|c|c|}
\hline Hypothesis & Path & Path Coefficient & $t$-Statistics & $p$-Values \\
\hline (H4) & $\begin{array}{l}\text { Entrepreneurial Passion for } \\
\text { Inventing -> EI }\end{array}$ & 0.259 & 2.970 & 0.000 \\
\hline (H5) & $\begin{array}{c}\text { Entrepreneurial } \\
\text { Passion for Founding -> EI }\end{array}$ & 0.315 & 3.125 & 0.002 \\
\hline (H6) & $\begin{array}{c}\text { Entrepreneurial } \\
\text { Passion forDeveloping -> EI }\end{array}$ & 0.236 & 2.192 & 0.001 \\
\hline
\end{tabular}

Note-Interaction was found to be significant at the $1 \%$ meaning level, i.e., $p<0.01$ using Andrew F. Hayes process macros with orientation to 5000 .

\subsection{Coefficients of Determination $\left(R^{2}\right)$}

$\mathrm{R}^{2}$ value obtained could interpret the structural model's strength, therefore indicating the exogenous variables' explanatory variance in the endogenous variable (Hair et al. 2017). The combined effect of variables on endogenous latent variable EI is 0.531 , indicating a positive relationship of the variables' total impact.

\subsection{Discussion}

EP plays a vital role in the development of EI in students. Very few studies have been conducted to empirically test the association between EPI, EPF, EPD, and EI. This study aims to fill this gap. The aim of the study is to examine the impact of EP on EI and the moderating role of PUS. The findings indicate that there is a significant and positive relationship between EPI $(\beta=0.104, p<0.000), \operatorname{EPF}(\beta=0.217, p<0.001)$, and EPD $(\beta=0.098, p<0.002)$ with EI. Therefore, hypotheses $(\mathrm{H} 1),(\mathrm{H} 2)$, and $(\mathrm{H} 3)$ are supported. The literature supports this view, that EP has a substantial part in the growth of EI. Therefore, the findings of the earlier studies also support the impact between these constructs (Cardon et al. 2013; Anjum et al. 2020b; Karimi 2019). Further, we already have identified with the results that PUS moderated the impact EP (inventing, founding, and developing) on EI.

Unemployment is at historic highs in most developing economies at the time of this publication, and governments need to adopt a policy to promote entrepreneurship as a means of lowering unemployment. Evidence shows the development of EI is vital to the existence of startups (Biraglia and Kadile 2016). Across 50 economies-including 11 in Europe-less than $2 \%$ of adults start new businesses; at the same time, low entrepreneurship rates, along with common growth aspirations, significantly reduce the employment potential of startups. Early-Stage entrepreneurship activity varies widely across the globe; only $1 \%$ of adults in seven economies-Canada, the United States, Panama, Germany, Ireland, Cyprus, and Puerto Rico-appear remarkably consistent to start new businesses or services. No one in their sample of entrepreneurs were starting a business and setting up new products or services in six economies Brazil, India, Pakistan, Oman, Belarus, or Morocco (Bosma et al. 2020). In this regard, the present study explores the mechanism by which EP influences the EI via the moderating role of the PUS.

\section{Conclusions}

The importance of entrepreneurship in creating wealth in society and businesses has been emphasized by many scholars. Entrepreneurship represents a driving force for the creation of new job opportunities, regional and national competitiveness and growth, and having substantial economic and social benefits (Vodă and Florea 2019; Farrukh et al. 2018; Harris et al. 2014). Although a vast variety of factors play a significant role in the decision to become an entrepreneur, our main focus was directed towards the role of passion towards entrepreneurial intention and role of university support for the students. Passion has a significant impact on entrepreneurs' behavior and performance, and it is essential to understand how entrepreneurial passion develops over time. Passion is determined by academia as a powerful and central driving force that influences business activities and efforts. A specific individual feature, entrepreneurial passion, can show a significant part 
in stockholder policy-making, counting angel stakeholders. This is because passion shows how entrepreneurs are willing to spend time and effort to make the business successful. Entrepreneurs can be more persuasive when they show high levels when positive and confidence (Anjum et al. 2018a; Obschonka et al. 2019).

In particular, the aim of this study was to examine whether and how EP affects the formation of EI within the TPB and moderation role of PUS. It was concluded that the entrepreneurial passion for inventing, founding, and developing have a significant positive association with entrepreneurial intention. Furthermore, the perception of university support has a positive moderating effect on entrepreneurial passion (inventing, founding, and developing) and entrepreneurial intention. In the entrepreneurship domain, a crucial attribute that needs to be well-established in every new startup is the entrepreneurial intention with passion. This study may involve educators (university support) who make increasingly focused contributions to potential entrepreneurs to discover their passions or identify new specific business aspects that will help them become more enthusiastic. Therefore, the development of passion is a necessary tool for the success of specific business activities. The research findings highlighted the association between these constructs and did research, which revealed that it is difficult to emphasize the association between passion and entrepreneurial intention. However, posited that passion is more useful for the enhancement of entrepreneurial intention if there is university support.

Additionally, the university's contribution in developing the knowledge to identify entrepreneurial opportunities, determined to increase the consideration of the socio-economic on the entrepreneurial university, employed institutional economics, resource-based view, and endogenous growth approaches (Neneh 2020; Anjum et al. 2021). The reality about enterprise education came to light as practical-based entrepreneurial learning. Both government and university support failed to yield the expected result of graduate engagement in entrepreneurship behavior in both situations. There also seemed to be a mismatch between the program and the individual student's personality, further revealing the complexity of graduate entrepreneurship (Ahmed et al. 2019). The study also encouraged the commercialization strategies essential to a university program in developing students' capacity. Attention was, however, drawn to the evaluation of the effectiveness of entrepreneurship education and the reconsideration of applying support services by universities.

\subsection{Theoretical and Practical Implications}

Both theoretical and practical contributions are included in this research. A greater role of passion in recognizing student's motives for their future acts is illustrated in this report. Adding PUS as the moderator of the EP-EI relationship creates a passion for research of the meaning behind entrepreneurship. These factors also expose the TPB hypothesis that additional exogenous variables such as passion indirectly affect individual intentions through their impact on the preceding intentions (Ajzen 1991). Moreover, the study also developed a non-Western context based on the role of EPs. Contemporary business research is mainly concentrated in Western countries, and this study increases the focus on emerging economies such as Pakistan. The current study adds to the literature by considering the EP influencing mechanism in a Pakistani context. This study's practical importance is for training and education programs for current and future entrepreneurs (students) with university support. The results confirm the view that EP will be an important parameter in the EI configuration. Politicians and academics must, therefore, prioritize university programs, thus generating more influential business education. Educational entrepreneurship programs should emphasize technical skills such as business planning and emotional aspects (Zreen et al. 2019).

\subsection{Limitations and Future Research}

First, the study sample was narrow to business students studying in the province of Punjab, Pakistan. Therefore, the student sample may not represent common student behavior in Pakistan. Second, the current study is based on cross-cutting information. Like 
all cross-sectional studies, correlation evidence should be interpreted with caution before a causal relationship is assumed. Third, convenience sampling was used to select and approach students, and the study sample size of $\mathrm{N}=395$ is significant but not large. Hence, future studies could collect additional data from all provinces of Pakistan for more rigorous and reliable results. Thus, testing and analyzing the present study framework in other nations or regions such as Austria, China, or Spain with significant cultural differences can offer fruitful findings. Demographics could also play a role in determining EI, and it is recommended that future studies be conducted to assess their impact. Future studies would benefit from experiments and longitudinal design to clarify causation.

Author Contributions: Conceptualization, T.A.; methodology, T.A., A.A., P.H.; formal analysis, T.A., A.A.; investigation, T.A and R.T.A.; writing-original draft preparation, T.A.; writing-review and editing, P.H. and T.A.; project administration, T.A. and P.H. All authors have read and agreed to the published version of the manuscript.

Funding: This research received no external funding.

Institutional Review Board Statement: Not applicable.

Data Availability Statement: Data can be provided on request.

Conflicts of Interest: The authors declare no conflict of interest.

\section{Appendix A}

\section{Questionnaire items}

\section{Entrepreneurial Passion for Inventing}

It is thrilling to understand new ways to resolve virgin market requirements, which can become realized.

I am looking for fresh ideas for products/services to propose and make them realistic.

I am motivated to upgrade the existing products/services.

Coming up with new and improved solutions to problems is an essential part of who I am. Examining the work environment for fresh opportunities motivates me.

\section{Entrepreneurial Passion for Founding}

Setting up a new company makes me feel enthusiastic.

Having my own business energizes me.

Providing support to a new business model during its emerging success is scintillating. To be the pioneer of a venture is an essential element of who I am.

\section{Entrepreneurial Passion for Developing}

I like finding the right people to market my product/service.

Assembling the right people to work for my business is exciting.

Pushing my employees and myself to make our company better motivates me.

Nurturing and growing companies is an essential part of who I am.

I really enjoy commercializing new products/services.

Expanding my company by offering new products and services excites me.

\section{Perception of University Support}

The entrepreneurship course provides students with the understanding required to begin a new business.

In my business school, students are receiving support to pursue their entrepreneurial career.

My university has well-functioning infrastructure support in place to support the startup of a new firm.

The innovative environment of my university encourages us to build up ideas for new startups.

In my university, I get to meet up with lots of people with creative and budding ideas. 


\section{Entrepreneurial Intention}

I will choose a career as an entrepreneur.

I prefer to be an entrepreneur rather than to be an employee in a company an Organization. The idea is appealing of one day starting your own business.

I want the freedom to express myself in my own business.

Intend to set up a company in the future.

\section{References}

Adekiya, Adewale A., and Fatima Ibrahim. 2016. Entrepreneurship Intention among Students. The Antecedent Role of Culture and Entrepreneurship Training and Development. International Journal of Management Education 14: 116-32. [CrossRef]

Ahmed, Tariq, Jane E. Klobas, and T. Ramayah. 2019. Personality Traits, Demographic Factors and Entrepreneurial Intentions: Improved Understanding from a Moderated Mediation Study. Entrepreneurship Research Journal, 1-16. [CrossRef]

Ajzen, Icek. 1991. The Theory of Planned Behavior. Organizational Behavior and Human Decision Processes 50: 179-211. [CrossRef]

Ajzen, Icek. 2011. The Theory of Planned Behaviour: Reactions and Reflections. Psychology and Health 26: 1113-27. [CrossRef] [PubMed]

Ali, Mohamed Salih Yousif, and Emad Aldeen Essa Eshag Abou. 2020. Determinants of Entrepreneurial Intention among Sudanese University Students. Management Science Letters 10: 2849-60. [CrossRef]

Aman, Lizawati, Amran Harun, and Zuhal Hussein. 2012. The Influence of Environmental Knowledge and Concern on Green Purchase Intention the Role of Attitude as a Mediating Variable. International Journal of Multicultural and Multireligious Understanding 6: 627. [CrossRef]

Anderson, James C., and David W. Gerbing. 1988. Structural Equation Modeling in Practice: A Review and Recommended Two-Step Approach. Psychological Bulletin 103: 411-23. [CrossRef]

Anjum, Temoor, Sara Ravan Ramzani, Nifa Nazar, Imran Ahmed Shahzad, and Shahrukh Salman. 2018a. Entrepreneurial Intention: Does Entrepreneurial Education Matter in Pakistan? International Journal of Human Resource Studies 8: 147-61. [CrossRef]

Anjum, Temoor, Sara Ravan Ramzani, Muhammad Farrukh, Valliappan Raju, Nida Nazar, and Imran Ahmad Shahzad. 2018b. Entrepreneurial Intentions of Pakistani Students: The Role of Entrepreneurial Education, Creativity Disposition, Invention Passion \& Passion for Founding. Journal of Management Research 10: 76. [CrossRef]

Anjum, Temoor, Shiva Sharifi, Nida Nazar, and Muhammad Farrukh. 2018c. Determinants of Entrepreneurial Intention in Perspective of Theory of Planned Behaviour. Management Theory and Studies for Rural Business and Infrastructure Development 40: 429-41. [CrossRef]

Anjum, Temoor, Sara Ravan Ramzani, and Nida Nazar. 2019. Antecedents of Entrepreneurial Intentions: A Study of Business Students from Universities of Pakistan. International Journal of Business and Psychology 1: 72-88.

Anjum, Temoor, Azadeh Amoozegar, Nida Nazar, and Nagina Kanwal. 2020a. Intervening Effect of Attitudes towards Entrepreneurship: Correlation between Passion and Entrepreneurial Intention. International Journal of Advanced Science and Technology 29: 1327-40.

Anjum, Temoor, Ramani Bai V., and Siew Poh Phung. 2020b. Moderating Role of University Support on the Relationship between Effective Entrepreneurship Education and Entrepreneurial Intention. Test Engineering Management 83: $16377-87$.

Anjum, Temoor, V. Ramani Bai, and Nida Nazar. 2020c. Mediating Role of Attitudes to Enhance the Creativity Disposition towards Entrepreneurial Intention. International Journal of Psychosocial Rehabilitation 24: 542-53. [CrossRef]

Anjum, Temoor, Muhammad Farrukh, Petra Heidler, and Julián Andres Díaz Tautiva. 2021. Entrepreneurial Intention: Creativity, Entrepreneurship, and University Support. Journal of Open Innovation: Technology, Market, and Complexity 7: 1-13.

Ansari, Nabeel Younus, Temoor Anjum, Muhammad Farrukh, and Petra Heidler. 2021. Do Good, Have Good: A Mechanism of Fostering Customer Pro-Environmental Behaviors. Sustainability 13: 3781. [CrossRef]

Bazzy, Joshua D., Adam R. Smith, and Teresa Harrison. 2019. The Impact of Abstract Thinking on Entrepreneurial Intentions. International Journal of Entrepreneurial Behaviour and Research 25: 323-37. [CrossRef]

Biraglia, Alessandro, and Vita Kadile. 2016. The Role of Entrepreneurial Passion and Creativity in Developing Entrepreneurial Intentions: Insights from American Homebrewers. Journal of Small Business Management 55: 170-88. [CrossRef]

Bonneville-Roussy, Arielle, Robert J. Vallerand, and Thérèse Bouffard. 2013. The Roles of Autonomy Support and Harmonious and Obsessive Passions in Educational Persistence. Learning and Individual Differences 24: 22-31. [CrossRef]

Bosma, Niels, Stephen Hill, Aileen Ionescu-somers, Donna Kelley, Jonathan Levie, and Anna Tarnawa. 2020. Global Entrepreneurship Monitor. Available online: https:/ / www.babson.edu/media/babson/assets/global-entrepreneurship-monitor/2019-2020-GEMGlobal-Report.pdf (accessed on 23 April 2021).

Cardon, Melissa S., and Colleen P. Kirk. 2015. Entrepreneurial Passion as Mediator of the Self-Efficacy to Persistence Relationship. Entrepreneurship: Theory and Practice 39: 1027-50. [CrossRef]

Cardon, Melissa S., Joakim Wincent, Jadgip Singh, and Mateja Drnovsek. 2005. Entrepreneurial Passion: The Nature of Emotions in Entrepreneurship. Briarcliff Manor: Academy of Management.

Cardon, Wincent J., Jadgip Singh, and Mateja Drnovsek. 2009. The nature and experience of entrepreneurial passion. Academy of Management Review 34: 511-32. [CrossRef] 
Cardon, Melissa S., Denis A. Gregoire, Christopher E. Stevens, and Pankaj C. Patel. 2013. Measuring Entrepreneurial Passion: Conceptual Foundations and Scale Validation. Journal of Business Venturing 28: 373-96. [CrossRef]

Collewaert, Veroniek, Frederik Anseel, Michiel Crommelinck, Alain De Beuckelaer, and Jacob Vermeire. 2016. When Passion Fades: Disentangling the Temporal Dynamics of Entrepreneurial Passion for Founding. Journal of Management Studies 53: 966-95. [CrossRef]

De Mol, Eva, Melissa S. Cardon, Bart de Jong, Svetlana N. Khapova, and Tom Elfring. 2019. Entrepreneurial Passion Diversity in New Venture Teams: An Empirical Examination of Short- and Long-Term Performance Implications. Journal of Business Venturing 35: 105965. [CrossRef]

Farrukh, Muhammad, Shams-Ur Rehman, and Amir Ishaque. 2016. Religion and Entrepreneurial Intentions: An Empirical Investigation. International Journal of Advanced and Applied Sciences 3: 31-36. [CrossRef]

Farrukh, Muhammad, Chong Wei Ying, and Shaheen Mansori. 2017. Organizational Commitment: An Empirical Analysis of Personality Traits. Journal of Work-Applied Management 9: 18-34. [CrossRef]

Farrukh, Muhammad, Yazan Alzubi, Imran Ahmad Shahzad, Abdul Waheed, and Nagina Kanwal. 2018. Entrepreneurial Intentions. Asia Pacific Journal of Innovation and Entrepreneurship 12: 399-414. [CrossRef]

Farrukh, Muhammad, Jason Wai Chow Lee, and Imran Ahmed Shahzad. 2019a. Intrapreneurial Behavior in Higher Education Institutes of Pakistan: The Role of Leadership Styles and Psychological Empowerment. Journal of Applied Research in Higher Education 11: 273-94. [CrossRef]

Farrukh, Muhammad, Jason Wai Chow Lee, Muhammad Sajid, and Abdul Waheed. 2019b. Entrepreneurial Intentions The Role of Individualism and Collectivism in Perspective of Theory of Planned Behaviour. Education + Training 67: 984-1000. [CrossRef]

Fayolle, Alain, and Benoit Gailly. 2015. The Impact of Entrepreneurship Education on Entrepreneurial Attitudes and Intention: Hysteresis and Persistence. Journal of Small Business Management 53: 75-93. [CrossRef]

Fayolle, Alain, and Francisco Liñán. 2014. The Future of Research on Entrepreneurial Intentions. Journal of Business Research 67: 663-66. [CrossRef]

Ferreira, João J., Cristina I. Fernandes, and Vanessa Ratten. 2016. Entrepreneurial Universities_Exploring the Academic and Innovative Dimensions of Entrepreneurship in Higher Education. Change: The Magazine of Higher Learning 32: 4-5. [CrossRef]

Fornell, Claes, and David F. Larcker. 1981. Evaluating Structural Equation Models with Unobservable Variables and Measurement Error. ЭкономикаРегиона 18: 32.

Hair, Joe F., Marko Sarstedt, Lucas Hopkins, and Volker G. Kuppelwieser. 2014. Partial Least Squares Structural Equation Modeling (PLS-SEM): An Emerging Tool in Business Research. European Business Review 26: 106-21. [CrossRef]

Hair, Joseph F., Jr., Tomas M. Hult, Christian Ringle, and Marko Sarstedt. 2017. A Primer on Partial Least Squares Structural Equation Modeling (PLS-SEM). New York: Sage Publications.

Harris, Michael L., Shanan G. Gibson, and William C. McDowell. 2014. The Impact of Strategic Focus and Previous Business Experience on Small Business Performance. Journal of Small Business Strategy 24: 29-44.

Hayes, Andrew F. 2007. Introduction to Mediation, Moderation, and Conditional Process Analysis. International Journal of Operations $\mathcal{E}$ Production Management 51: 335-37.

Henseler, Jörg, Christian M. Ringle, and Rudolf R. Sinkovics. 2009. The Use of Partial Least Squares Path Modeling in International Marketing. Advances in International Marketing 20: 277-319. [CrossRef]

Iglesias-Sánchez, Patricia P., Carmen Jambrino-Maldonado, and Carlos de las Heras-Pedrosa. 2019. Training Entrepreneurial Competences with Open Innovation Paradigm in Higher Education. Sustainability 11: 4689. [CrossRef]

Joensuu, Sanna, Anmari Viljamaa, Elina Varamäki, and Erno Tornikoski. 2013. Development of Entrepreneurial Intention in Higher Education and the Effect of Gender-A Latent Growth Curve Analysis. Education and Training 55: 781-803. [CrossRef]

Joensuu, Elina Varamäki, Erno Tornikoski Sanna, and Anmari Viljamaa. 2015. The Development of Entrepreneurial Potential among Higher Education Students. Journal of Small Business and Enterprise Development 22: 563-89.

Joensuu-Salo, Sanna, Anmari Viljamaa, and Elina Varamäki. 2020. Do Intentions Ever Die? The Temporal Stability of Entrepreneurial Intention and Link to Behavior. Education and Training 62: 325-38. [CrossRef]

Karimi, Saeid. 2019. The Role of Entrepreneurial Passion in the Formation of Students' Entrepreneurial Intentions. Applied Economics 52: 331-44. [CrossRef]

Katbla, Riitta, and Gautam Ahuja. 2002. Sometfflng Old, something new: A longitudinal study of search behavior and new product introduction. Academy of Management Journal 45: 1183-94.

Keat, OoiYeng, Christopher Selvarajah, and Denny Meyer. 2011. Inclination towards Entrepreneurship among University Students: An Empirical Study of Malaysian University Students. International Journal of Business and Social Science 2: 206-20. [CrossRef]

Krueger, Norris, Michael D. Reilly, and Alan L. Carsrud. 2000. Competing Models of Entrepreneurial Intentions. Journal of Business Venturing 15: 411-32. [CrossRef]

Lee, Lena, Poh Kam Wong, Maw Der Foo, and Aegean Leung. 2011. Entrepreneurial Intentions: The Influence of Organizational and Individual Factors. Journal of Business Venturing 26: 124-36. [CrossRef]

Liñán, Francisco, David Urbano, and Maribel Guerrero. 2011. Regional Variations in Entrepreneurial Cognitions: Start-up Intentions of University Students in Spain. Entrepreneurship and Regional Development 23: 187-215. [CrossRef]

Mageau, Geneviève A., and Robert J. Vallerand. 2007. The Moderating Effect of Passion on the Relation between Activity Engagement and Positive Affect. Motivation and Emotion 31: 312-21. [CrossRef] 
Mandongwe, Lucia, and Divaries C. Jaravaza. 2020. Women Entrepreneurial Intentions in Subsistence Marketplaces: The Role of Entrepreneurial Orientation and Demographic Profiles in Zimbabwe. Cogent Business and Management 7: 1818365. [CrossRef]

Manley, Scott C., Joseph F. Hair, Ralph I. Williams, and William C. McDowell. 2020. Essential New PLS-SEM Analysis Methods for Your Entrepreneurship Analytical Toolbox. International Entrepreneurship and Management Journal, 1-21. [CrossRef]

Murnieks, Charles Y., Elaine Mosakowski, and Melissa S. Cardon. 2014. Pathways of Passion: Identity Centrality, Passion, and Behavior Among Entrepreneurs. Journal of Management 40: 1583-606. [CrossRef]

Murnieks, Charles Y., Melissa S. Cardon, Richard Sudek, T. Daniel White, and Wade T. Brooks. 2016. Drawn to the Fire: The Role of Passion, Tenacity and Inspirational Leadership in Angel Investing. Journal of Business Venturing 31: 468-84. [CrossRef]

Mustafa, Michael James, Ernesto Hernandez, Christopher Mahon, and Lai Kei Chee. 2016. Entrepreneurial Intentions of University Students in an Emerging Economy: The Influence of University Support and Proactive Personality on Students' Entrepreneurial Intention. Journal of Entrepreneurship in Emerging Economies 8: 162-79. [CrossRef]

Nabi, Ghulam, Francisco Liñá, Alain Fayolle, Norris Krueger, and Andreas Walmsley. 2017. The Impact of Entrepreneurship Education in Higher Education: A Systematic Review and Research Agenda. Academy of Management Learning and Education 16: 277-99. [CrossRef]

Nazar, Nida, Sarwat Jahan, Azadeh Amoozegar, Temoor Anjum, and Valliappan Raju. 2020. The Effects of Total Quality Management Practices on Corporate Social Responsibility Using Supply Chain Model: A Review of Malaysian Hotel Industry. International Journal of Supply Chain Management 9: 294-304.

Neneh, Brownhilder Ngek. 2020. Studies in Higher Education Entrepreneurial Passion and Entrepreneurial Intention: The Role of Social Support and Entrepreneurial Self-Efficacy. Studies in Higher Education, 1-17. [CrossRef]

Nyock, Ilouga S., Nyock Mouloungni, and Jean Michel Sahut. 2014. Entrepreneurial Intention and Career Choices: The Role of Volition. Small Business Economics 42: 717-28. [CrossRef]

Obschonka, Martin, Julia Moeller, and Maximilian Goethner. 2019. Entrepreneurial Passion and Personality: The Case of Academic Entrepreneurship. Frontiers in Psychology 9: 2697. [CrossRef] [PubMed]

Saeed, Rashid, Hafiza Hafsa Nayyab, Haroon Rashied, Rab Nawaz Lodhi, Shireen Musawar, and Anam Iqbal. 2013. Who Is the Most Potential Entrepreneur? A Case of Pakistan. Middle East Journal of Scientific Research 17: 1307-15. [CrossRef]

Saeed, Saadat, Shumaila Y. Yousafzai, Mirella Yani-De-Soriano, and Moreno Muffatto. 2015. The Role of Perceived University Support in the Formation of Students' Entrepreneurial Intention. Journal of Small Business Management 53: 1127-45. [CrossRef]

Sahban, Muhammad Amsal, Subramaniam Sri Ramalu, and Ruswiati Syahputra. 2016. The Influence of Social Support on Entrepreneurial Inclination among Business Students in Indonesia. Information Management and Business Review 3: 32-46. [CrossRef]

Souitaris, Vangelis, Stefania Zerbinati, and Andreas Al-Laham. 2007. Do Entrepreneurship Programmes Raise Entrepreneurial Intention of Science and Engineering Students? The Effect of Learning, Inspiration and Resources. Journal of Business Venturing 22 : 566-91. [CrossRef]

Türk, Sarah, Florian B. Zapkau, and Christian Schwens. 2020. Prior Entrepreneurial Exposure and the Emergence of Entrepreneurial Passion: The Moderating Role of Learning Orientation. Journal of Small Business Management 58: 225-58. [CrossRef]

Turker, Duygu, and Senem Sonmez Selcuk. 2009. Which Factors Affect Entrepreneurial Intention of University Students? Journal of European Industrial Training 33: 142-59. [CrossRef]

Vallerand, Robert J., Nathalie Houlfort, and Jacques Fores. 2003. Emerging Perspectives on Values in Organizations. Google Books. Charlotte: IAP.

Vallerand, Robert J., Geneviève A. Mageau, Andrew J. Elliot, Alexandre Dumais, Marc André Demers, and François Rousseau. 2008. Passion and Performance Attainment in Sport. Psychology of Sport and Exercise 9: 373-92. [CrossRef]

Vodă, Ana Iolanda, and Nelu Florea. 2019. Impact of Personality Traits and Entrepreneurship Education on Entrepreneurial Intentions of Business and Engineering Students. Sustainability 11: 1192. [CrossRef]

Wardatulaina, Sitinor, Mohd Yusof, Juhaini Jabar, Murzidah Ahmad Murad, and Rosalina Torres Ortega. 2017. International Journal of Advanced and Applied Sciences Exploring the Cultural Determinants of Entrepreneurial Success: The Case of Malaysia. International Journal of Advanced and Applied Sciences 4: 287-97.

Westhead, Paul, and Mike Wright. 2015. The Habitual Entrepreneur Phenomenon. International Small Business Journal 44: 1-16.

Wong, Ken Kwong-Kay. 2013. Partial Least Squares Structural Equation Modeling (PLS-SEM) Techniques Using SmartPLS. Marketing Bulletin 24: 1-32.

Zreen, Aneeqa, Muhammad Farrukh, Nida Nazar, and Rimsha Khalid. 2019. The Role of Internship and Business Incubation Programs in Forming Entrepreneurial Intentions: An Empirical Analysis from Pakistan. Journal of Management and Business Administration. Central Europe 27: 97-113. [CrossRef] 